\title{
KRITIK HUKUM ISLAM TERHADAP PENDAPAT IMAM AL-SYÂFI'Î DAN IBNU HAZM TENTANG NAFKAH BAGI ISTRI NUSYUZ
}

\author{
Ummi Mar'atus Sholihah \\ Peneliti INSERT Foundation Bandung Jawa Barat \\ E-mail:maratus_ummi@yahoo.com
}

\begin{abstract}
Nafkah is one of the important things in the household. Therefore, the rules relating to nafkah is needed to be studied. However, there is a different opinion among the jurists on the issue of the nafkah, such as a matter of nafkah for wives who nushuz. Imams Al-Syâfi'î, one of the leading jurists and one of the imams mazhab argued that a wife who nushuz could abort a right to get nafkah, unless she returned from her nushuz (disobedience). This perspective is different with the opinion of Ibn Hazm which he stated that providing nafkah for wife who nushuz is allowed. He was due to differences methodology and basic laws that are based on the determining of the jurisdictions and laws through both their opinion about nafkah for nushuz's wife.
\end{abstract}

\begin{abstract}
Abstrak
Nafkah merupakan salah satu hal penting dalam rumah tangga. Oleh karenanya, aturan yang berhubungan dengan nafkah sangat diperlukan untuk dikaji. Namun demikian, terdapat beberapa perbedaan pendapat dikalangan para fuqaha mengenai permasalahan nafkah ini, diantaranya adalah masalah nafkah bagi isteri yang nusyuz. Imam Al-Syâfi'î, yaitu salah satu fuqaha terkemuka dan merupakan salah satu imam mazhab berpendapat, bahwa isteri yang nusyuz dapat menggugurkan hak mendapatkan nafkah, kecuali isteri telah kembali dari nusyuznya. Konsep ini berbeda dengan pendapat Ibnu Hazm yang menyatakan bahwa nafkah bagi isteri yang nusyuz adalah boleh, hal ini disebabkan karena perbedaan metode dan dasar hukum yang digunakan sebagai landasan dalam menetapkan hukum suatu masalah oleh kedua Imam tersebut tentang nafkah bagi isteri yang nusyuz.
\end{abstract}

Kata kunci:

Hukum Islam, Nafkah, Suami, Isteri, Nusyuz

\section{A. Pendahuluan}

Salah satu aspek kehidupan umat manusia yang telah diatur oleh syarî‘at Islam adalah pernikahan. Pernikahan merupakan gerbang untuk memasuki dan mengarungi kehidupan keluarga yang bertujuan untuk membentuk suatu ikatan keluarga yang harmonis. Ketentraman dalam sebuah keluarga merupakan dambaan bagi setiap keluarga dalam membina rumah tangganya menuju cita-cita kehidupan keluarga yang bahagia dan sejahtera yang diliputi rasa kasih sayang, kedamaian dan ketentraman, bebas dari ancaman dan kekhawatiran serta rasa takut. Allah SWT berfirman dalam surat Al-Rûm ayat 21:

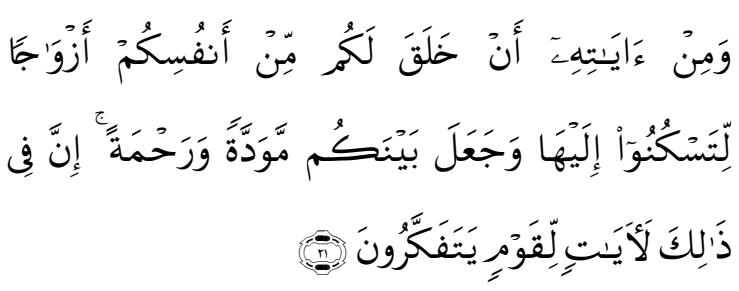

Dan di antara tanda-tanda kekuasaan-Nya ialah Dia menciptakan untukmu isteri-isteri dari jenismu sendiri, supaya kamu cenderung dan merasa tenteram kepadanya, dan dijadikan-Nya diantaramu rasa kasih dan sayang. Sesungguhnya pada yang demikian itu be- 
nar-benar terdapat tanda-tanda bagi kaum yang berfikir. ${ }^{1}$

Perkawinan adalah suatu ikatan antara seorang pria dengan seorang wanita. Jika seorang wanita dan laki-laki telah melangsungkan aqad, maka masing-masing dari keduanya disebut suami dan isteri. Oleh karena itu, masing-masing darinya bertanggung jawab terhadap penderitaan dan cita-citanya. Dengan demikian, masing-masing suami-isteri mempunyai hak dan kewajiban yang harus dijaga baik-baik. Hak dan kewajiban itu berlaku sama, kecuali yang memang secara fitrah dikhususkan untuk laki-laki atau perempuan. Allah SWT berfirman dalam surat Al-Bâqarah ayat 228:

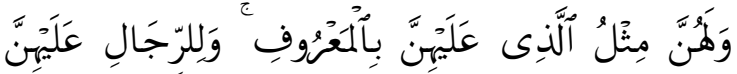

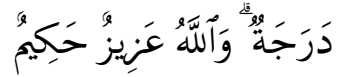

Dan para wanita mempunyai hak yang seimbang dengan kewajibannya menurut cara yang ma'ruf. akan tetapi Para suami, mempunyai satu tingkatan kelebihan daripada isterinya dan Allah Maha Perkasa lagi Maha Bijaksana. $^{2}$

Kelebihan yang dimaksud dalam ayat ini, yaitu kelebihan mengurus dan bertanggung jawab. Oleh karena itu, seorang suami muslim tidak dibenarkan mengabaikan masalah nafkah dan pakaian isteri, karena seorang suami merupakan kepala keluarga yang bertanggung jawab terhadap kebutuhan isterinya, baik kebutuhan bathiniah atau kebutuhan lahiriyah. Akad nikah yang telah dilaksanakan oleh pasangan suami isteri menyebabkan isteri terikat oleh hak-hak suaminya dan haram untuk dinikahi orang lain. Dan ikatan tersebut menyebabkan suami wajib memberi nafkah kepada isterinya.

Sebagaimana firman Allah SWT dalam surat Al-Nisâ ayat 34 yang berbunyi:

'Soenarjo, Al-Quran dan Terjemahnya (Semarang: Toha Putra. 1989), hlm. 644.

${ }^{2}$ lbid. hlm. 55.

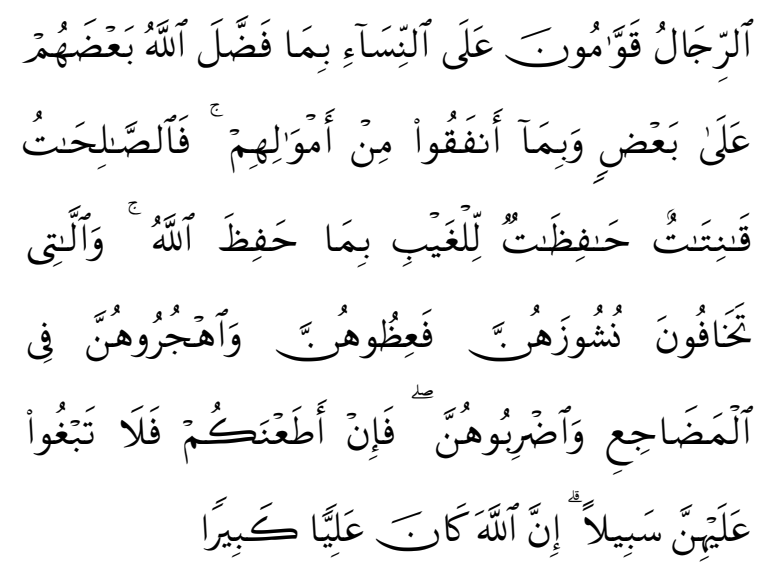

Kaum laki-laki itu adalah pemimpin bagi kaum wanita, oleh karena Allah telah melebihkan sebahagian mereka (laki-laki) atas sebahagian yang lain (wanita), dan karena mereka (laki-laki) telah menafkahkan sebagian dari harta mereka. Sebab itu Maka wanita yang saleh, ialah yang taat kepada Allah lagi memelihara diri ketika suaminya tidak ada, oleh karena Allah telah memelihara (mereka). Wanita-wanita yang kamu khawatirkan nusyuznya, maka nasehatilah mereka dan pisahkanlah mereka di tempat tidur mereka, dan pukullah mereka. kemudian jika mereka mentaatimu, Maka janganlah kamu mencaricari jalan untuk menyusahkannya. Sesungguhnya Allah Maha Tinggi lagi Maha besar.

Dalam ayat ini, pada kenyataannya menunjukkan bahwa hubungan suami isteri tidak selamanya dipelihara secara harmonis. Munculnya perubahan pandangan hidup yang berbeda antara suami dan isteri, menimbulkan perselisihan dalam rumah tangga yang merubah suasana harmonis menjadi percekcokan, kasih sayang menjadi kebencian. Sehingga mengakibatkan pasangan suami isteri tidak dapat melaksanakan hak dan kewajibannya masing-masing sesuai dengan perjanjian pernikahan.

Salah satu perbuatan yang melanggar pernikahan adalah perilaku isteri yang berbuat nusyuz, artinya ia (seorang istri) tidak melaksanakan hak dan kawajibannya terhadap suami. Perbuatan isteri seperti ini berakibat buruk terhadap keharmonisan hubungan pernikahan dan aspek-aspek lain yang berhubungan dengan ikatan pernikahan. 
Diantara aspek yang berhubungan dengan pernikahan itu adalah kewajiban suami untuk memberi nafkah kepada isterinya. Tetapi, apakah isteri masih berhak untuk mendapatkan nafkah ketika ia berbuat nusyuz (membangkang terhadap suaminya), atau memang hak isteri untuk mendapatkan nafkah itu, menjadi gugur.

Para ulama berbeda pendapat mengenai nafkah bagi isteri yang nusyuz, diantaranya ialah Imam Al-Syâfiî̀ dan Ibnu Hazm. AlSyâfi'î mengatakan bahwa:

$$
\begin{aligned}
& \text { ولوهربت أوامتنعت أوكانت أمة فمنعها سيدها فلانفقة لها } \\
& \text { ولايبرئه مما وجب لها من نفقتها وإن كان حاضرا } \\
& \text { معهاإلا إقرارهاؤوبينة تقوم عليه }
\end{aligned}
$$

Jika isterinya melarikan diri, atau enggan melayani syahwat suaminya, atau jika isteri seorang hamba sahaya dan tuan isterinya melarang untuk bersetubuh dengan suaminya, maka suaminya tidak berkewajiban menafkahi isterinya. ${ }^{3}$

Maksud dari isteri yang nusyuz itu sendiri adalah seorang isteri yang membangkang atau menolak perintah suami dimana isteri tidak dapat melaksanakan kewajibannya terhadap suami, salah satu perbuatan nusyuz itu sendiri yaitu seorang isteri yang menolak untuk mencampuri oleh suaminya dan melarikan diri dari tanggung jawabnya, seperti yang dikemukakan oleh Al-Syâfîi di atas bahwa jika isterinya melarikan diri dan enggan melayani suaminya maka suaminya tidak berkewajiban menafkahi isterinya.

Sedangkan Ibnu Hazm menyatakan bahwa:

$$
\begin{aligned}
& \text { وينفق الرجل على امرأته من حين يعقد نكاحهادعى إلى }
\end{aligned}
$$

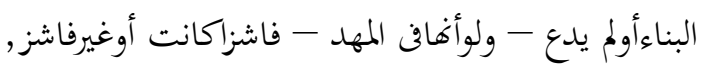

$$
\begin{aligned}
& \text { غنية كانت أوفقيرة, ذات أب كانت أويتيمة, بكراأوثيبا, } \\
& \text { حرة كانت أوأمة - على قدرماله. }
\end{aligned}
$$

Suami berkewajiban menafkahi isterinya sejak terjalin akad nikah, baik suami mengajaknya hidup serumah atau tidak, baik isteri masih dalam buaian, isteri nusyuz atau tidak

${ }^{3}$ Abû 'Abdullâh Al-Syâfi'î, Al-Umm (Beirut: Dâr alKitâb al-'Alamiyyah. t.th.), juz.VIII, hlm. 33 . nusyuz, kaya atau fakir, mempunyai bapak atau yatim, gadis atau janda, merdeka atau budak, semuanya disesuaikan oleh kemampuan suami.

Alasan Ibnu Hazm didasarkan pada sabda Rasul SAW:

$$
\text { ولمن عليكم رزقهن وكسوتن بالمعروف (رواه مسلم) }
$$

Mereka berhak mendapat belanja dari kamu dan pakaian dengan cara yang ma'rûf. (HR. Muslim $)^{4}$

Zhahir hadits di atas menghendaki pemberian nafkah bagi seluruh isteri, tanpa ada suatu batasan, apabila ia (isteri) nusyuz atau tidak, tetap berhak untuk mendapatkan nafkah.

\section{B. Dasar Hukum Menurut Al-Syâfi'î dan Ibnu Hazm}

\section{Dasar Hukum Menurut Al-Syâfi ${ }^{\circ}$}

Seperti Imam Madzhab lainnya, Imam Al-Syâfi'î menentukan dasar hukum tersendiri. Adapun langkah-langkahnya menurut AlSyâfi'î adalah sebagai berikut: "Asal adalah Al-Quran dan al-Hadits, apabila tidak ada dalam Al-Quran dan al-Hadits, maka ia melakukan qiyas terhadap keduanya. Apabila Hadits telah muttashil dan sanadnya shahih, maka Hadits tersebut telah berkualitas (muntaha). Makna Hadits yang diutamakan adalah makna zhahir, beliau menolak hadits munqathi' kecuali yang diriwayatkan oleh Ibn Musayyab, pokok (al-ashl) tidak boleh dianalogikan kepada pokok, bagi pokok tidak perlu dipertanyakan mengapa dan bagaimana karena (mengapa dan bagaimana) dipertanyakan hanya kepada cabang (far'u). ${ }^{5}$

Menurut Al-Syâfi'î, urutan sumber hukum Islam adalah:

a. Al-Quran dan Al-Sunnah, sebagai sumber hukum pokok;

b. Bila tidak terdapat dalam Al-Quran dan al-Sunnah, beliau berpindah kepada ljma'; dan

\footnotetext{
${ }^{4}$ Ibn Hazm, Al-Muhalla (Beirut: Dâr al-Afaq alJadîdiyyah. 1980), juz. XI, hlm. 321.

${ }^{5}$ Jaih Mubarok, Modifikasi Hukum Islam (Studi tentang Qawl Qadim dan Qawl Jadid) (Jakarta: PT Raja Grafindo Persada. 2001), hlm. 31.
} 


\section{c. Al-Qiyash.}

Al-Syâfîî beristinbath dengan mensejajarkan Al-Quran dan Al-Sunnah, hal ini dilakukan karena keduanya tercakup dalam pengertian wahyu. Namun, beliau mengakui bahwa Al-Sunnah tidak sekuat Al-Quran. AlSunnah tidak akan pernah bertentangan dengan Al-Quran. Bila ditemukan teks AlQuran bertentangan dengan al-hadits, sesuai dengan teorinya bahwa al-Hadits berfungsi menjelaskan Al-Quran, maka Al-Quran harus ditafsirkan dengan sudut pandang Al-Hadits. Dengan demikian yang dimaksud dengan AlHadits di sini adalah Al-Hadits yang telah dibuktikan meyakinkan berasal dari Nabi SAW tidak lain kecuali Hadits shahih. Hanya saja, ukuran bahwa sebuah riwayat itu shahih adalah apabila sanadnya shahih. ${ }^{6}$

Dilihat dari sudut lafazh, Imam Al-Syâfi'î berhujjah dengan 'amm. la tidak meninggalkan umum selama belum ada mukhashishnya, hanya saja Al-Syâfiî̀ mengkhususkan umum dengan Hadits Ahad karena dalalah 'amm menurutnya adalah zhanniyah.?

Sumber syarî‘at sesudah Al-Quran dan Al-Hadits menurut Al-Syâfi'î adalah ljma'. Yang dimaksud dengan ljma' di sini adalah kesepakatan seluruh ulama dalam kurun waktu yang sama, dan tidak ada seorang pun yang menyatakan perselisihan pendapatnya dalam kasus yang dicari kesepakatannya. Menurut beliau kesepakatan para sahabat adalah kesepakatan yang paling kuat. ${ }^{8}$

Imam Al-Syâfîi juga mengutip perkataan sahabat, dan harus didahulukan dari kajian akal mujtahid, karena menurutnya pendapat mereka lebih baik dari pada hasil kajian mujtahid. Untuk itu beliau berargumentasi, para sahabat itu lebih pintar, lebih taqwa dan lebih wara'. Oleh sebab itu, mereka lebih berkompeten untuk melakukan ijtihad dari pada para ulama sesudahnya. Produk ijtihad mereka yang dinyatakan lewat ijma' harus diterima secara mutlak. Sedangkan yang dikeluar-

\footnotetext{
${ }^{6}$ Muh. Zuhri, Hukum Islam dalam Lintasan Sejarah (Jakarta: PT Raja Grafindo Persada. 1996), hlm. 113.

${ }^{7}$ Hasbi Ash-Shiddieqy, Pokok-pokok Pegangan Imam Madzhab (Semarang: PT Pustaka Rizki Putra. 1997), hlm. 245.

${ }^{8}$ Muh. Zuhri, Hukum Islam. hlm. 116.
}

kan lewat fatwa-fatwa individual boleh diterima dan boleh tidak, dengan menganalisis dasar-dasar fatwanya. ${ }^{9}$

Sedangkan mengenai qiyash, Imam AlSyâfiî̂ merupakan mujtahid pertama yang menguraikan dasar qiyash. Al-Syâfiî̂ membuat kaidah-kaidah yang harus dipegang dalam menentukan mana ra'yu yang shahih dan yang tidak shahih. la membuat kriteria bagi istinbath yang salah. Beliau menentukan batas-batas qiyash, martabat-martabatnya, dan kekuatan hukum yang ditetapkan dengan qiyash. Juga diterangkan syarat-syarat yang harus sempurna pada qiyas. ${ }^{10}$

\section{Dasar Hukum Menurut Ibnu Hazm}

Dasar hukum menurut Ibnu Hazm, beliau mengutamakan Al-Quran dan Al-Hadits. Apabila tidak terdapat dalam Al-Quran dan Al-Hadits Ibnu Hazm menggunakan ljma، sahabat sebagai sumber ketiga, dan apabila tidak terdapat dalam ljma' sahabat Ibnu Hazm menggunakan dalîl. Langkah-langkah ijtihad Ibnu Hazm ini dikemukakan dalam penjelasannya yang dikutip oleh Jaih Mubarok dalam bukunya "Sejarah dan Perkembangan Hukum Islam", yaitu:

$$
\begin{aligned}
& \text { الاصول التى لايعرفو شيىمن الشارع الامنهاربعة,وهي نص } \\
& \text { القران ونص كلام رسول الله صلى الله عليه وسلم الذي انما } \\
& \text { هوعن الله محاصح عنه عليه السلام ونقله الثقات } \\
& \text { اوالتواترواجمع العلماءالاثمةودليل منهالايحتمل الاوجهاواحدا. }
\end{aligned}
$$

Dasar-dasar yang tidak diketahui dari syara melainkan dari pada dasar itu ada empat, yaitu nash Al-Quran, nash kalam Rasulullah yang sebenarnya datangnya dari Allah juga yang shahih kita terima dari padanya dan dinukilnya oleh orang-orang kepercayaan atau yang Mutawatir dan yang ljma' oleh semua umat dan suatu dalil dari padanya yang tidak mungkin menerima, selain satu cara. ${ }^{11}$

Mengenai Al-Quran dan Al-Hadits, Ibnu Hazm satu pendapat dengan Al-Syâfi î, bah-

\footnotetext{
${ }^{9}$ Dede Rosyada, Hukum Islam dan Pranata Sosial (Jakarta: PT Raja Grafindo Persada. 1996), hlm. 151.

${ }^{10}$ Hasbi Ash-Shiddieqy, Pokok-pokok Pegangan. hlm. 256.

"Jaih Mubarok, Modifikasi Hukum. hlm. 153.
} 
wa Al-Quran dan Al-Hadits merupakan sumber hukum pokok. Beliau juga sependapat dalam mengutamakan makna zhahir dalam Al-Quran dan Al-Hadits. ${ }^{12}$

Sumber hukum yang terakhir adalah dalîl, menurut lbnu Hazm dalîl ada yang diambil dari nash dan ijma', dalîl yang diambil dari nash yaitu:

a. Nash yang terdiri dari dua muqaddimah, yaitu muqaddimah kubra dan muqaddimah shughra tanpa natijah, karena mengeluarkan natijah dari dua muqaddimah tersebut termasuk al-Dalîl;

b. Penerapan segi keumuman makna;

c. Makna yang ditunjuk oleh suatu lafazh mengandung penolakan terhadap makna lain yang tidak mungkin bersesuaian dengan makna yang dikandung oleh lafazh tersebut;

d. Apabila sesuatu tidak ada nash yang menentukan hukumnya, apabila wajib dilakukan atau haram, maka hukumnya adalah mubah;

e. Qadhaya Mudrajah, yaitu pemahaman bahwa derajat yang tertinggi itu dipastikan berada di atas derajat yang lain yang berada di bawahnya;

f. Aqsha al-qhadllaya, yaitu pemahaman yang menyatakan bahwa setiap kulliyât senantiasa berlawanan dengan juz'iyatnya;

g. Cakupan yang merupakan keharusan yang menyertai makna dimaksud.

Adapun dalil-dalil yang diambil dari ijma‘, terbagi pada empat bagian, yaitu:

a. Istishab al-hâl, yaitu kekalnya hukum ashl yang telah tetap berdasarkan nash, hingga ada dalil tertentu yang menunjukkan adanya perubahan;

b. 'Aqallu mâ qilla, yaitu target minimal atau terendah dari suatu ukuran yang diperselisihkan;

c. Ijma‘ ulama untuk meninggalkan suatu pendapat;

d. Ijma، ulama tentang universalitas hukum; ${ }^{13}$

\footnotetext{
${ }^{12}$ Ibid. hlm. 153.

${ }^{13}$ Ibid. hlm. 154-160.
}

\section{Kedudukan Hukum Nafkah bagi Isteri Nusyuz menurut Al-Syâfi'î dan Ibnu Hazm}

\section{Kedudukan Hukum Nafkah bagi Isteri Nusyuz menurut Al-Syâfi'î}

Kedudukan hukum nafkah bagi isteri yang nusyuz, menurut kesepakatan para imam madzhab, hukumnya adalah haram dan dapat menggugurkan hak nafkah. Masing-masing suami isteri wajib berlaku yang baik terhadap pasangannya dan masing-masing wajib memenuhi hak pasangannya dengan senang hati dan tidak menunjukkan kebencian. Oleh karena itu, isteri wajib taat kepada suaminya, tetap tinggal di rumah, dan suami berhak melarangnya keluar dari rumah. Suami pun wajib membayar mahar serta memberi nafkah. Demikian menurut ljma' para imam madzhab. ${ }^{14}$

Alasan lain bagi jumhur ulama adalah bahwa nafkah yang diterima isteri merupakan imbalan dari ketaatan yang diberikan kepada suami. Oleh karena itu, Isteri nusyuz (hilang ketaatannya) pada suami dalam suatu masa dalam pernikahan, ia tidak berhak atas nafkah yang diberikan oleh suami selama masa nusyuz dan kewajiban itu kembali dilakukan setelah nusyuz itu berhenti. ${ }^{15}$

Madzhab Syâfi'î dalam masalah ini memiliki dua pendapat, pendapat lama dan pendapat baru. Menurut pendapat lama, nafkah menjadi wajib sejak dilaksanakan akad nikah dan menjadi berlaku terus dengan penyerahan diri wanita untuk digauli. Seandainya ia menolak dan tidak memberikan kesempatan kepada suaminya, maka nafkahnya menjadi hilang, karena yang menggugurkan haknya adalah dirinya sendiri.

Adapun menurut pendapat baru yang dijadikan landasan bagi mereka dan ini dianut pula oleh madzhab Hambali, bahwa nafkah tidak wajib hanya dengan dilaksanakan akad nikah, karena akad hanya mewajibkan adanya mahar, tidak mewajibkan dua unsur yang diganti yang berbeda, yaitu mahar dan

\footnotetext{
${ }^{14}$ Syekh Al-'Allâmah Muhammad Ibn 'Abdurrahmân Al-Dimasyqi, Fiqih Empat Madzhab (Bandung: Hasyimi Press. 2004), hlm. 361.

${ }^{15}$ Amir Syarifuddin, Hukum Perkawinan Islam di Indonesia (Jakarta: Kencana Prenada Media Group. 2007), hlm. 173.
} 
nafkah. Ini disebabkan karena ketidakjelasan nominal pada nafkah. Sedangkan akad tidak mengharuskan adanya harta yang tidak diketahui. Rasulullah menikahi 'Aisyah ketika ia masih berumur enam tahun. Dua tahun kemudian Rasulullah baru menggaulinya. Tidak pernah diriwayatkan bahwa beliau memberikan nafkah kepadanya sebelum menggaulinya. Bila nafkah itu menjadi haknya, tentunya Rasulullah tidak akan menahannya dan seandainya pernah dilakukan oleh beliau, tentunya akan sampai pada kita. ${ }^{16}$

Al-Syâfiî̀ dalam kitabnya Al-Umm mengatakan:

$$
\begin{aligned}
& \text { قال: ولابحب النفقةلإمرأةحتى تدخل على زوجها, أوتخلي } \\
& \text { بينه وبين الدخول عليها, فيكون الزوج بترك ذلك, } \\
& \text { فإذاكانت هي المتنعة من الدخول عليه فلا نفقة لها, لأهما } \\
& \text { مانعة له نفسها. وكذالك أن هربت منه, أومنعته الدخول } \\
& \text { عليها بعد الدخول عليه, لم يكن لمانفقة ماكانت متتنعة } \\
& \text { منه. قال الشافعي: وإذا نكحها ثم خلت بينه وبين الدخول } \\
& \text { عليهافلم يدخل فعليه نفقتها, لأن الحبس من قبله. }
\end{aligned}
$$

Dan tiada wajib nafkah bagi isteri sehingga ia masuk kepada suaminya atau ia membiarkan dirinya diantara sumi dan masuk suami itu kepadanya. Lalu suami itu membiarkan yang demikian. Maka apabila isteri itu tidak mau masuk kepada suami, niscaya tiada nafkah bagi isteri tersebut. Karena ia menjadi penghalang untuk suaminya. Seperti demikian juga, kalau isteri itu melarikan diri dari suami atau melarang suami bersetubuh kepadanya, sesudah masuk kepada suami. Maka tidak ada nafkah bagi isteri tersebut, selama ia mencegah dirinya dari suami. Syâfiî̀ berkata: apabila seseorang mengawini seorang wanita, kemudian wanita tersebut menyerahkan dirinya untuk bersetubuh, lalu suami itu tidak bersetubuh. Maka atas suami itu nafkahnya. Karena pemahaman itu dari pihak suami. ${ }^{17}$

\footnotetext{
${ }^{16}$ Muhammad Ya'qub Thâlib Ubaydi, Nafkah Isteri (Hukum Menafkahi Iseteri dalam Perspektif Islam) (Jakarta: Darus Sunnah. 2007), hlm. 60.

${ }^{17}$ Abû 'Abdullâh Al-Syâfi'i, Al-Umm. Juz. V, hlm. 128.
}

$$
\begin{aligned}
& \text { ولوهربت أوامتنعت أوكانت أمة فمنعها سيدها فلا نفقة لما }
\end{aligned}
$$

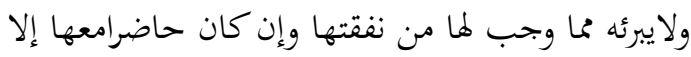

$$
\begin{aligned}
& \text { إقرارها أوبينة تقوم عليه }
\end{aligned}
$$

Jika isterinya melarikan diri, atau enggan melayani syahwat suaminya, atau jika isterinya seorang hamba sahaya dan tuan isterinya melarang untuk bersetubuh dengan suaminya, maka suaminya tidak berkewajiban menafkahi isterinya. ${ }^{18}$

Dalam qawl qadîm Al-Syâfi'î berpendapat bahwa sebab suami berkewajiban memberi nafkah kepada isterinya adalah akad perkawinan, karena akad nikah menghalalkan persetubuhan (istimta') dan istimta' wajib dilakukan karena akad. Sedangkan dalam qaul jadîd, Al-Syâfi'î berpendapat bahwa sebab suami berkewajiban memberi nafkah kepada isterinya adalah jimak (persetubuhan), karena apabila nafkah wajib karena akad maka suami yang menceraikan isterinya sebelum dijimak diwajibkan membayar seluruh mahar yang telah ditentukan. ${ }^{19}$

Selain itu dikatakan dalam sumber lain terdapat beberapa masalah yang berkaitan dengan persoalan nusyuz dan taat, diantaranya yaitu:

a. Apabila isteri murtad, menurut kesepakatan seluruh madzhab, kewajiban nafkah menjadi gugur, tetapi nafkah tetap wajib bagi isteri ahli kitab seperti isteri muslimah, tanpa ada perbedaan sedikitpun;

b. Apabila isteri meninggalkan rumah tanpa izin suami, atau menolak tinggal di rumah (suami) yang layak baginya, maka ia dianggap sebagai isteri nusyuz, menurut kesepakatan seluruh madzhab, dia tidak berhak atas nafkah;

c. Kalau isteri bersedia digauli dan tinggal bersama suaminya kapan saja suaminya ia menghendaki, tetapi kasar dalam berbicara, kurang ajar dan acap kali melawan dalam banyak hal seperti banyak hal yang dilakukan banyak wanita, apa-

\footnotetext{
${ }^{18}$ Ibid. Juz. VIII, hlm. 337.

${ }^{19}$ Jaih Mubarok, Modifikasi Hukum. hlm. 262.
} 
bila perbuatan ini merupakan watak asli isterinya maka tidak menjadikan gugurnya nafkah namun bila bukan merupakan watak aslinya artinya dia bersikap baik terhadap orang lain tapi tidak terhadap suaminya, maka dia dianggap nusyuz dan tidak berhak atas nafkah;

d. Apabila isteri tidak mau menuruti suaminya kecuali sesudah dia memperoleh mahar kontannya, menurut para ulama madzhab, masalah mahar melakukan pemisahan antara ketidakbersediaan isteri sebelum digauli suami, dengan ketidakbersediaannya sesudah digauli suami secara sukarela sebelum menerima maharnya. Dalam hal yang pertama, ketidaksediaannya mempunyai yustifikasi syara', sehingga dia tidak dipandang sebagai isteri yang nusyuz. Sedangkan dalam hal yang kedua, ketidaksediaannya itu tidak memiliki yustifikasi syara', sehingga dia dianggap sebagai isteri yang nusyuz;

e. Apabila isteri mengurung diri dari suami dengan maksud agar suami memenuhi nafkah atau maharnya, namun bila suami memang tidak mampu memenuhi kewajiban materilnya, maka kewajiban memberi nafkah gugur. Tetapi bila suami mampu tapi sengaja menunda, maka hak isteri atas nafkah tidak terputus;

f. Apabila seorang isteri diceraikan suaminya ketika dalam keadaan nusyuz, maka isteri tidak berhak atas nafkah. Kalau dia dalam keadaan 'iddah dari thalaq raj'i, lalu melakukan nusyuz saat menjalani 'iddahnya, maka haknya atas nafkah menjadi gugur. Kemudian bila dia kembali taat, maka nafkahnya diberikan terhitung dari waktu ketika diketahui dia kembali taat. $^{20}$

\section{Kedudukan Hukum Nafkah bagi Isteri Nusyuz menurut lbnu Hazm}

Sudah dimaklumi bahwa rukun pokok perkawinan adalah adanya ridha laki-laki dan perempuan serta persetujuan mereka untuk mengikat hidup berkeluarga. Dalam persetu-

${ }^{20}$ Muhammad Jawâd Mughniyyah, Fiqh Lima Madzhab (Beirut: Dâr al-Jawad. 1996), hlm. 403-407. juan tersebut mereka juga terikat untuk melaksanakan hak dan kewajibannya dalam rumah tangga sesuai dengan perannya masingmasing sebagai suami isteri. Suami sebagai kepala keluarga memiliki kewajiban yang harus dilaksanakannya, yang mana kewajiban ini merupakan hak isteri diantaranya yaitu melindungi dan memberikan biaya rumah tangga (nafkah) kepada keluarganya. Dan seorang isteri mempunyai kewajiban untuk melayani suaminya dan mentaati perintah suami selama perintah itu baik untuknya. Sebagai imbalan pelayanannya, maka ia berhak atas nafkah yang diberikan oleh suaminya.

Nafkah yang dimaksud dalam pembahasan ini adalah nafkah bagi isteri yang berbuat nusyuz (durhaka) terhadap suaminya menurut Ibnu Hazm. Ibnu Hazm sebagaimana yang telah diketahui, bahwa beliau adalah seorang tokoh fiqh yang menghidupkan fiqh zhahiri. Beliau memperlihatkan bahwa AlQuran dan cakupannya dapat menampung setiap peristiwa hukum di setiap tempat dan masa. ${ }^{21}$

Menurut empat imam madzhab, kedurhakaan isteri haram hukumnya (menghasilkan dosa) dan menggugurkan nafkah. Sedangkan Ibnu Hazm berpendapat bahwa kedurhakaan itu tidak menggugurkan nafkah karena nafkah itu bukan diwajibkan lantaran istimta' hanya diwajibkan karena pernikahan. $^{22}$

Dalam kitabnya Muhalla Ibnu Hazm mengatakan:

$$
\begin{aligned}
& \text { وينفق الرجل على امرأته من حين يعقد نكاحها إلى البناء }
\end{aligned}
$$

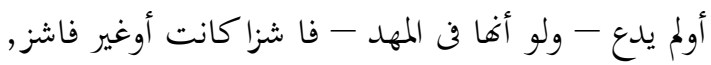

$$
\begin{aligned}
& \text { غنية كانت أوفقيرة, ذات أب كانت أويتيمة, بكرا أوثيبا, } \\
& \text { حرة كانت أو أمة - على قدر ماله. }
\end{aligned}
$$

Bahwa suami berkewajiban menjafkahi isterinya sejak terjalin akad nikah, baik suaminya mengajak hidup serumah atau tidak, baik isteri masih dalam buaian, isteri nusyuz atau tidak nusyuz, kaya atau fakir, mempunyai bapak atau yatim, gadis atau janda, merdeka

\footnotetext{
${ }^{21}$ Hasbi Ash-Shiddieqy, Hukum-hukum Fiqh Islam (Jakarta: Bulan Bintang. 1952), hlm. 553.

${ }^{22}$ Hasbi Ash-Shiddieqy, Pengantar Ilmu Fiqh (Jakarta: Bulan Bintang. 1967), hlm. 283.
} 
atau budak semuanya disesuaikan oleh kemampuan suami. ${ }^{23}$

Menurutnya bahwa seorang isteri yang telah melakukan akad nikah dengan suaminya, sejak pula ia berhak mendapatkan nafkah karena perkawinan itu sendirilah yang menjadi salah satu penyebab adanya kewajiban nafkah bagi suami terhadap isterinya. Baik suami serumah atau tidak dengan isterinya, isteri belum dewasa atau dewasa, isteri nusyuz atau tidak, kaya atau miskin, dan isteri yatim atau tidak semua itu disesuaikan dengan kemampuan suami. Untuk memperkuat ucapannya itu ia berkata:

$$
\begin{aligned}
& \text { برهان ذلك ماقد ذكرنا بإسناده قبل من قول رسوالله صلى } \\
& \text { الله عليه وسلم فن النساء ولهن عليكم رزقهن وكسوتهن } \\
& \text { بالمعروف, وهذا يوجدد لهن النفقة من حين العقد وقال }
\end{aligned}
$$

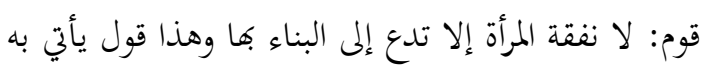

$$
\begin{aligned}
& \text { قرأن ولا سنة ولا قول صاحب ولا قياس ولا رأي له وجهه. }
\end{aligned}
$$

Dalil-dalil yang demikian itu: pendapat Ibnu Hazm sebagaimana yang disebutkan diatas, yaitu mengambil sandaran dari Hadits Rasulullah SAW tentang wanita-wanita "Dan bagi mereka (isteri-isteri) atas tanggungan rizki (nafkah) mereka dan pakaian mereka dengan cara yang ma'rûf". Dalil-dalil ini menunjukkan kewajiban memberi nafkah bagi mereka (isteri-isteri) mulai sejak adanya akad nikah). Sebagian golongan mereka berkata: "Tidak ada nafkah bagi isteri sekira-kira ia berniat mengajak untuk hidup berumah tangga. Pendapat ini (menurut Ibnu Hazm) tidak beralasan, tidak ada pendapat sahabat, qiyas dan tidak ada pula suatu pemikiran ke arah itu. ${ }^{24}$

Selain itu, Ibnu Hazm berkata: Abû Sulymân serta sahabat-sahabatnya dan AlTsawri berkata, bahwa nafkah itu wajib dibayarkan kepada isteri yang masih kecil sejak ia dinikahi. Selanjutnya Ibnu Hazm berkata: sama sekali tidak ada keterangan dari para sahabat tentang perempuan nusyuz kemudian tidak berhak menerima nafkah, keterangan

\footnotetext{
${ }^{23}$ Ibn Hazm, Al-Muhalla. hlm. 321.

${ }^{24}$ Ibnu Hazm, Al-Muhalla. hlm. 321.
}

ini hanya berasal dari Al-Nakha'i, Al-Sya'bi, Hammad bin Sulaymân, Al-Hasan dan AlZuhri, kami tidak tahu apa alasan mereka selain semata-mata karena soal hubungan kelamin, kalau isteri tidak mau dicampuri, maka ia tidak berhak menerima nafkah. ${ }^{25}$

Sebagaimana yang telah dikemukakan di atas mengenai kedudukan nafkah bagi isteri yang nusyuz menurut Ibnu Hazm, bahwa nusyuznya isteri tidak menjadi penghalang mendapatkan hak atas nafkah yang diberikan oleh suaminya. Menurut Ibnu Hazm nafkah itu merupakan kewajiban yang harus diberikan oleh suami kepada isterinya sejak akad nikah berlangsung meskipun isteri itu nusyuz atau tidak.

\section{Persamaan dan Perbedaan Pendapat Al- Syâfi'î dan Ibnu Hazm tentang Hukum Nafkah bagi Isteri Nusyuz. \\ 1. Persamaan}

Adapun persamaan pendapat dari kedua Imam tersebut yaitu:

a. Al-Syâfi'î dan Ibnu Hazm sependapat dalam memandang Al-Quran dan Al-Hadits, dua bagian yang satu sama lainnya saling menyempurnakan, yang kedua-duanya dinamakan nushush;

b. Sependapat bahwa nafkah merupakan kewajiban yang harus diberikan oleh suami kepada isteri setelah adanya akad atau dalam perkawinan;

c. Sependapat dalam mengutamakan zhahir lafazh.

\section{Perbedaan}

Perbedaan pendapat dari kedua Imam tersebut yaitu:

a. Perbedaan pendapat dalam menetapkan hukum nafkah bagi isteri yang nusyuz Al-Syâfiî̀ berpendapat bahwa isteri yang nusyuz terhadap suaminya dapat menggugurkan haknya atas nafkah pemberian suami. Sedangkan Ibnu Hazm menyatakan bahwa selama terjalinnya ikatan perkawinan atau setelah terjadinya akan nikah suami wajib mem-

\footnotetext{
${ }^{25} \mathrm{Al}-\mathrm{Hamdani}$, Risalah Nikah (Jakarta: Pustaka Amani. 2002), hlm. 128.
} 
beri nafkah kepada isterinya baik isteri tersebut nusyuz atau tidak;

b. Berbeda dalam mengeluarkan dalil, AlSyâfiî̂ berargumen dengan bersumber pada Al-Quran suran Al-Nisâ ayat 34 yang menerangkan tentang kewajiban isteri untuk taat kepada suami karena telah memberikan nafkah kepadanya dan sanksi bagi isteri yang nusyuz. Sedangkan Ibnu Hazm berargumen dengan Hadits riwayat Muslim, pendapat sahabat 'Umar, dan riwayat dari Syu'bah yang menerangkan secara umum bahwa nafkah wajib bagi isteri sejak berlangsungnya akad, dikarenakan itu merupakan kewajiban dan perintah yang harus dikerjakan;

c. Berbeda dalam metode istinbath hukum, Al-Syâfiîi dalam beristinbath hukum dengan menggunakan Al-Quran sebagai sumber. Sedangkan Ibnu Hazm menggunakan metode istinbath hukum dengan mengambil zhahir lafazh pada Hadits dengan lafazh yang bersifat umum.

\section{E. Penutup}

Berdasarkan uraian di atas, nafkah bagi isteri yang nusyuz menurut Al-Syâfîî dan Ibnu Hazm tersebut di atas, secara umum dapat di ambil beberapa kesimpulan sebagai berikut:

1. Al-Syâfi î̀ berpendapat bahwa isteri yang berbuat nusyuz terhadap suaminya maka hak atas nafkah menjadi gugur dan suami tidak wajib memberikan nafkah sampai ia kembali dari nusyuznya. Sedangkan Ibnu Hazm lain pula beliau berpendapat bahwa nusyuz tidak menggugurkan nafkah;

2. Landasan hukum yang dijadikan sandaran oleh Al-Syâfi'î dalam menetapkan hukum nafkah bagi isteri yang nusyuz adalah berdasarkan kepada nash Al-Quran suran Al-Nisâ ayat 34. Sedangkan landasan hukum yang dijadikan sandaran oleh Ibnu Hazm adalah Hadits Nabi SAW yang diriwayatkan oleh Muslim dari Jabir, pendapat sahabat Umar bin Khattab dan riwayat dari Syu'bah. Menurutnya dalil-dalil tersebut bersifat umum, yang berlaku bagi setiap isteri yang telah melakukan akad nikah dan selama masih ada ikatan suami isteri selama itu pula ada hak nafkah. Tidak terikat oleh keadaan dan sikap isteri yang berhak atas nafkah tersebut;

3. Metode Istinbath al-Ahkâm (cara pengambilan hukum) yang digunakan Al-Syâfi î dalam menentukan berlakunya hak nafkah bagi isteri nusyuz ini adalah berpegang pada Al-Quran surat Al-Nisâ ayat 34 dengan makna yang zhahir. Sedangkan metode Istinbath al-Ahkâm yang digunakan Ibnu Hazm dalam menentukan hukum nafkah bagi isteri nusyuz adalah berpegang Hadits Nabi SAW yang diriwayatkan oleh Muslim dari Jabir, pendapat sahabat Umar bin Khattab dan riwayat dari Syu'bah;

4. Persamaan Al-Syâfiî̀ dan Ibnu Hazm dalam mengeluarkan pendapat tentang nafkah bagi isteri yang nusyuz adalah bahwa Al-Syâfiî̀ dan Ibnu Hazm sependapat mengenai nafkah merupakan kewajiban yang harus diberikan suami kepada isteri setelah berlangsungnya akad dan selama perkawinan itu berlangsung. Sedangkan perbedaan pendapat antara Al-Syâfi'î terletak pada metode Istinbath al-Ahkâm yang digunakan serta berbeda dalam menetapkan hukum tentang nafkah bagi isteri nusyuz.

\section{Daftar Pustaka}

Ash-Shiddieqy, Hasbi. 1952. Hukum-hukum Fiqh Islam. Jakarta: Bulan Bintang. . 1967. Pengantar Ilmu Fiqh. Jakarta: Bulan Bintang.

Dimasyqi. Muhammad Ibn 'Abdurrahmân, al. 2004. Fiqih Empat Madzhab. Bandung: Hasyimi Press.

Hamdani, al-. 2002. Risalah Nikah. Jakarta: Pustaka Amani.

Hazm, Ibn. 1980. Al-Muhalla. Beirut: Dâr alAfaq al-Jadidiyah.

Mubarok, Jaih. 2001. Modifikasi Hukum Islam (Studi tentang Qawl Qadim dan Qawl Jadid). Jakarta: PT Raja Grafindo Persada. 
Mughniyah, Muhammad Jawâd. 1996. Fiqh Lima Madzhab. Beyrut: Dâr al-Jawad.

Rosyada, Dede. 1996. Hukum Islam dan Pranata Sosial. Jakarta: PT RajaGrafindo Persada.

- 1997. Pokok-pokok Pegangan Imam Madzhab. Semarang: PT Pustaka Rizki Putra.

Soenarjo. 1989. Al-Quran dan Terjemahnya. Semarang: Toha Putra.

Syâfi'î, Abi 'Abdillâh, al-. t.th. Al-Umm. Beyrut: Dâr al-Kitâb al-'Alamiyah.
Syarifuddin, Amir. 2007. Hukum Perkawinan Islam di Indonesia. Jakarta: Kencana Prenada Media Group.

Ubaidi, Muhammad Ya'qub Thâlib. 2007. Nafkah Isteri (Hukum Menafkahi Iseteri dalam Perspektif Islam). Jakarta: Darus Sunnah.

Zuhri, Muh. 1996. Hukum Islam dalam Lintasan Sejarah. Jakarta: PT RajaGrafindo Persada. 